\title{
A FOREIGN OFFICE SURVEY OF VENEREAL DISEASE AND PROSTITUTION CONTROL, 1869-701
}

\author{
by
}

\section{J. B. POST*}

RECENT INTEREST in the Contagious Diseases Acts, ${ }^{2}$ and in the comparative study of prostitution under state regulation in the nineteenth century, ${ }^{3}$ suggests that a medical, legal and statistical survey carried out by the Foreign Office in 1869-70 on behalf of the Privy Council may be worthy of attention. The information gathered was never eventually put to official use, and the papers have in consequence survived, misleadingly to the searcher, among the records of the Foreign Office; they remain, however, a remarkable collection of comparative material, drawn as far as possible from official sources at roughly similar dates, and their history is also instructive.

Demands for legislative action against venereal diseases in the armed forces had led to the Contagious Diseases Acts of 1864 and 1866, which provided for the compulsory examination and, if necessary, hospitalization of prostitutes working in and around specified military and naval centres. ${ }^{4}$ The measures were conceived primarily as improvements to military efficiency, and as such caused very little stir in parliament or elsewhere, ${ }^{5}$ but gradually they prompted a lengthy and bitter controversy in

\section{*J. B. Post, M.A., D.Phil., Public Record Office, Kew, Richmond, Surrey TW9 4DU.}

${ }^{1}$ I am very grateful to Dr. B. Harrison, Dr. P. F. McHugh, and Dr. A. M. S. Prochaska for their helpful comments on this paper in draft.

2 Of many studies, see especially F. B. Smith, 'Ethics and disease in the later nineteenth century: the Contagious Diseases Acts', University of Melbourne Historical Studies, 1971, 15: 118-135; R. L. Blanco, 'The attempted control of venereal disease in the army of mid-Victorian England', J. Soc. for Army Historical Research, 1967, 45: 234-241; E. M. Sigsworth and T. J. Wyke, 'A study of Victorian prostitution and venereal disease', in M. Vicinus (editor), Suffer and be still: women in the Victorian age, Bloomington and London, 1972, pp. 77-99; P. F. McHugh, 'The campaign against the contagious diseases acts: some organisational aspects 1869-86', unpublished $D$. Phil. thesis, Oxford, 1976. Five important items from the Westminster Review-one article by W. R. Greg, three by John Chapman, and an edited reprint of the relevant section of Simon's Eleventh Reporthave been reprinted as Prostitution in the Victorian age, with an introduction by $\mathbf{K}$. Nield, Farnborough, 1973. J. L. Hammond and Barbara Hammond, James Stansfeld: a Victorian champion of sex equality, London, Longmans, 1932, is a nalve hagiography, but its political account of the acts and their repeal (pp. 118-259) is predominantly accurate in its salient details.

' R. J. Evans, 'Prostitution, state, and society in imperial Germany', Past and Present, 1976, 70: 106-129 and references.

- Blanco, op. cit., note 2 above, passim. In 1925 S. W. Harris, an assistant secretary at the Home Office and British representative on the Permanent Advisory Committee of the League of Nations for Social Questions, prepared a lucid and balanced analysis of the acts and their subsequent history, now in HO 45/20044/455304, no. 56. All documents cited here are in the Public Record Office.

- Smith, op. cit., note 2 above, pp. 119-120; see also the comments of the Royal Commission of 1870-71: Parliamentary Papers, House of Commons, [hereinafter H.C.] 1871, 19, no. 408, paras 16-17. 


\section{J. B. Post}

which medical and moral prejudices were freely invoked on both sides. In 1868 a select committee of the House of Lords reported that "the cautious extension of the act may be safely entrusted to the government", preferably piecemeal at the request of individual localities. ${ }^{6}$ More vigorous discussion began in the same year, when an Association for the Extension of the Contagious Diseases Acts was formed to advocate the extension of these controls to the civil population as well as to the armed services in general. ${ }^{7}$ Among its supporters were numerous eminent medical men and churchmen, who emphasized their sympathies by submitting a memorial on the subject to the Lord President of the Council. This memorial asserted that the incidence of venereal diseases in garrison towns was abating; that many prostitutes had been "reclaimed"; that further controls would benefit both the armed services and "innocent adults and children"; that the diseases were rampant in many non-garrison towns; and that "it has been ascertained, the women themselves would not resist restrictions established to prevent them spreading contagious diseases":

Under these circumstances, we are of the opinion that the principle of 'The Contagious Diseases Act, 1866', should be extended to the civil population, by providing proper hospital accommodation for women suffering from, and likely to spread, such diseases, and by taking power to detain them in hospital when found to be diseased. These measures, in our opinion, do not involve any system of licensing prostitution. They are intended to be purely restrictive and sanitary in their operation.

This agitation was met at various levels: John Simon, the medical officer to the Privy Council, conducted his own investigations, and a Commons select committee considered the possibility of further legislation. Simon's evidence before the committee was based on his current annual report," where he made his position clear: "at present $I$ very decidedly refrain from recommending any change in that neutral position which English law has hitherto held in regard of the venereal diseases of the civil population". ${ }^{10}$ Less publicly, Simon thought it "quite reasonable" that the acts should be extended to other military and naval centres, but he objected vigorously to the broad terms of a bill drafted rather shoddily by the War Office and the Admiralty; on this advice, "as great objection is found to exist in many quarters to the extension of the provisions of this act to places other than military or naval stations", the Home Secretary was "not inclined to propose such extension until public opinion may be more favourable thereto", and the subsequent amending

- P.P., House of Lords, 1867-68, 30, no. 113. The Lords were apparently encouraged by the reported decrease in venereal diseases in the armed services: Hansard, 3rd ser., 192, cols. 324-330.

'Smith, op. cit., note 2 above, p. 121.

H.C., 1867-68, 55, no. 266: 30 April 1868.

- H.C., 1868-69, 7, no. 306, p. 70. For the background to Simon's Eleventh Report, and its reception, see R. Lambert, Sir John Simon, 1816-1904, and English social administration, London, MacGibbon \& Kie, 1963, pp. 405-406, and Nield, op. cit., note 2 above, John Chapman regarded Simon's statistics as partial and unreliable, but his own for Rotterdam do not tally with those supplied by the ministry of the interior: 'Prostitution: how to deal with it', Westminster Rev., new ser., 1870, 37: [also reprint, cited in note 2 above], pp. 501, 478.

${ }^{10}$ H.C., 1868-69, 32, no. 4127: Eleventh Report of the Medical Officer of the Privy Council, V ('Question of state interference to provide for the disinfection of prostitutes') [also reprint, cited in note 2 above], p. 16. 


\section{A Foreign Office survey of venereal disease and prostitution control, 1869-70}

legislation made only administrative changes, which were carried without debate. ${ }^{11}$

The idea of extending the acts was by no means dead. Before the select committee concluded its proceedings Simon was recalled to discuss the possible nature of evidence upon which an extension of the acts might be based. He had reservations about the speed with which such evidence could be gathered, and about the reliability of the results, but he made concrete suggestions:

... one wants to compare countries where prostitutes are under systematic sanitary regulation with countries where the commerce is not regulated; to compare the quantities of venereal diseases in the two classes of countries; and, in my opinion, very particularly to compare the quantities of true syphilis in the two classes of countries; and then, secondly, one wants to compare the now regulated countries in their present state with the same countries in their previous state of non-regulation. ${ }^{12}$

When asked about the means of obtaining such information, Simon said that his department could collaborate with the Foreign Office in drawing up a letter to foreign governments. ${ }^{13}$ "Particular questions would of course require a good deal of planning", and someone might have to visit the Continent to check details; even then the information would perhaps be inconclusive. Nonetheless the committee obviously favoured further explorations, and a survey was begun shortly afterwards.

Simon made his suggestions on 8 July 1869, and a survey was instituted by Foreign Office circular of 4 August. It stated that the Privy Council

are desirous, with a view to extending the provisions of the Contagious Diseases Act of 1866 to the civil population of this country, of obtaining from the various countries in Europe the most complete information which can be procured on the following points:-(A) as to the present prevalence of venereal diseases among the respective populations of those countries; (B) As to the laws and machinery which exist in certain of those countries or in parts of them, for the sanitary superintendence of prostitution; and (C) As to the amount and sorts of advantage which have accrued to the public health in each of those countries, or among particular classes, or in particular places in any of them, in consequence of such laws and machinery.

The circular then proceeded to detail the medical and statistical information required, and to emphasize the inadequacy of previous enquiries, in terms which leave no doubt that Simon attended to the drafting. Copies were sent to the British representatives in twenty-two major cities, and in most cases the returns survive. ${ }^{14}$

Returns to the circular trickled in slowly between September 1869 and the end of the following year, and in some instances no reply was forthcoming at all. ${ }^{15}$ The

1132 \& 33 Victoria, c.96; cf. Hansard, 3rd ser., 198, index s.v. Contagious Diseases Bill. The earlier draft bill, Simon's comments, and related papers, are in HO 45/9322/17273, nos. 5, 236.

12 H.C., 1868-69, 7, no. 306, Qs 1507-1528.

12 This course of action, and a draft questionnaire, had already been suggested to the Home Office in May 1869, by Berkeley Hill of the Extension Association: HO 45/9322/17273, no. 14.

14 A copy of the circular, a list of places circulated, and the surviving returns are bound together in FO 83/354. The returns are found country by country, but the volume has no internal numeration. Information and quotations from the returns are all taken from this volume. The places were Vienna, Darmstadt, Stuttgart, Munich, Copenhagen, Stockholm, Berlin, Dresden, Coburg. The Hague, Brussels, the Hanse towns, St. Petersburg, Florence, Paris, Berne, Rome, Athens, Constantinople, Madrid, Lisbon, and Washington.

${ }_{15}$ FO $83 / 522$ contains, under 13 July 1877 , a table of places circulated and the fate of their returns. Vienna, Darmstadt, Rome, Constantinople, Madrid, and Lisbon apparently failed to reply. 


\section{J. B. Post}

information provided was exceedingly varied in quantity and quality. The reply from Washington, for example, gave little help beyond quotations from, and sceptical references to, the latest published work on the subject. ${ }^{16} \mathrm{~A}$ long despatch from Athens discussed the enormous difficulty of furnishing any particulars, offered some heavily qualified statistics, and gave a few descriptive comments on municipal procedures for the control of prostitution. The brief replies from Florence and St. Petersburg enclosed some local information on controls, which is now missing. Other countries, however, are better represented, and it is here that the most useful information is to be found; the returns from Hamburg, Berne, Dresden, Paris, The Hague, and Stockholm are careful, elaborate, and often minute.

From Hamburg came an extensive report specially prepared by the chief municipal physician, Dr. Engel-Reimers. He gave a historical synopsis of the licensing system, a description of police regulations (especially as revised in 1866), and lengthy medical and statistical information, including a large map of the city showing the distribution of first-and second-class brothels. The statistics give a careful analysis of the numbers, ages, and origins of prostitutes, and comparative figures, said to be extremely reliable, for the incidence of venereal diseases in 1861 and 1868. Engel-Reimers declared himself a strong advocate of regulation, and considered that the detailed control in Hamburg was relatively successful; he complained, however, that clandestine prostitution, generally regarded as the major health hazard, ${ }^{17}$ was increasing, and pointed out that the numbers of prostitutes were increasing faster than the population at large, which was probably (in fact) a long-term function of industrialization to which regulation was virtually irrelevant. ${ }^{18}$ The same factors are likely to have affected Saxony, on which a report had been made by the medical board there. Burnley, the British chargé d'affaires in Dresden, apologized for the delay of more than a year, but commended the report as "valuable and complete". Although the statistics cover the whole kingdom, Burnley only included one set of regulations: "the police regulations of Chemnitz, Dresden, and Leipzig being absolutely identical, I have preferred adopting the Leipzig law owing to the large number of university students, and the probability of there being a larger number of this class of women". The surviving return from Stockholm, covering Norway, is a report of similar structure; though less extensive than those from Dresden and Hamburg, it contains particular and aggregated statistics of venereal diseases in various towns, chiefly 1856-66.

The return from The Hague not only contained a discursive report from the ministry of the interior, but also appended the local reports on which it had been based; these last included accounts of municipal regulations (in the case of Amersfoort, a printed copy), and some elaborate and very recent statistics. The Swiss return was on the same pattern, although much less attempt had been made to digest the local information, except for some general remarks by the chargé d'affaires in Berne. The report was essentially a précis of returns by cantonal governments to a circular from the federal council, and as such contained uneven amounts of descriptive and statistical

10 W. W. Sanger, The history of prostitution, New York, 1869.

${ }^{17}$ Prostitution was "clandestine" if it was not conducted under police surveillance, whether or not that surveillance was formal.

18 Evans, op. cit., note 3 above, pp. 107-108, 116-117. 


\section{A Foreign Office survey of venereal disease and prostitution control, 1869-70}

material. In general, prostitution in Switzerland was either illegal or beyond legal regulation, and details were correspondingly sparse. Doctors in Lucerne, however, were anxious that prostitution should be legalized and regulated; those in Basle felt that the illegality of prostitution, coupled with the exclusion of venereal diseases from treatment at public expense, enhanced the incidence of concealed disease, and they were campaigning for more liberal attitudes, which the police were gradually adopting. Most cantons had few data to offer, as explained by Obwalden: "Morality in this canton has happily not yet sunk to so low a level as to enable us to return instructive replies....".

Of all the returns, those from France were the most extensive, and the least organized. The only general material was a large table, showing department by department the incidence of prostitution, registered and unregistered, and the proportions of venereal diseases, together with brief marginal comments; an annotation in English attributes the figures to November 1868. Otherwise the return consists of such material as was obtained from the prefectures of the various departments. In many cases this information is statistical, but it is clear that the concern in France was as much for the control of prostitution as for the control of venereal disease. This is emphasized by the great quantity of printed official documents: there are regulations for St. Malo and Lille, police posters from Thionville and Metz, and prostitute identity cards from Metz and Toulouse, while Lyon provided a prostitute identity card, a complete printed list of prostitutes for tabulating their medical inspections, and a form for returning a clandestine prostitute to her native place. All these items show commendable attention to detail, but the statistics do not; there was little attempt to follow Simon's requirement that different types of venereal disease should be distinguished.

Despite the effectiveness of the Foreign Office circular, and the wealth of information contained in the returns, the papers were not put to any official purpose. There were several reasons for this. First, the report of the select committee of 1868-69, and the consequent amending legislation, reduced the impetus of further investigation. Second, the returns were bulky, heterogeneous, and in a variety of languages, and their content was thus not immediately accessible. Third, the task of reviewing the papers would have devolved on Simon, who had already made it clear that he was opposed to extension of the acts and was not anxious to foster the desire of the government to follow continental models; in 1878 the medical officer to the Local Government Board told his superiors "that he had reason to believe that some years ago an attempt to analyse these papers was undertaken under Mr. Simon's direction, but deliberately abandoned because it appeared to him that no trustworthy conclusions as to results could be derived from any analysis that might be made". ${ }^{10}$ Fourth, in partial justification of Simon's attitude, opposition to the acts was by now concerted and vigorous, and an association for the repeal of the acts was ranged against the association for

19 FO 83/556, 28 March 1878. Suspicion even of domestic statistics was growing. In 1871 an assistant commissioner of the Metropolitan Police told the Home Office that the Devonport and Plymouth returns under the Contagious Diseases Acts were falso-the Devonport Watch Committee had suppressed the true figures as "a lasting disgrace to the town", while the returning officer for Plymouth had "registered" as prostitutes many virtuous women and fictitious names in order to substantiate his opinions aired before the royal commission: HO 45/9322/17273, no. 137a. 


\section{J. B. Post}

their extension, ${ }^{20}$ in consequence of which a royal commission was appointed to review the whole problem. ${ }^{21}$ It was thus ironic but unsurprising that demands for publication of the survey should have come, eventually, from the abolitionists.

The Foreign Office circular was not a matter for secrecy, but knowledge that the returns existed seems to have been vague. In June $1877 \mathrm{Sir}$ Harcourt Johnstone ${ }^{22}$ wrote to Robert Bourke, under-secretary of state at the Foreign Office, asking if he might copy, for use at a medical congress in Geneva, information which he understood to have been collected in 1864-66; on the following day James Stansfeld, a dedicaied opponent of the acts and subsequently a member of the Commons select committee of 1879-82, also wrote, having been told of the statistics by "a Leipzig doctor". Bourke, on the basis of a minute by Staveley, a senior clerk, replied that the only known papers were the returns to the 1869 circular, that the task of transcription would be laborious, and that the Privy Council Office might have a digest. Meanwhile Staveley was attempting to retrieve the papers from the Local Government Board, whither they had been transferred when that body took over various public health functions from the Council in 1871; some were returned at once, others more than a month later, and some, despite a thorough search, were reported lost. Thomas, a clerk of the Board, said defensively (17 July) that "Mr. Sclater Booth [President of the Board] appeared to be at the time of opinion that it was not advisable to publish these returns, since from their incompleteness and other reasons they would be misleading to the public", but Booth himself claimed to have no objection to the production of the papers on a proposed Commons motion by Stansfeld, provided that the Foreign Office allowed the Board to inspect any version prepared for publication. ${ }^{23}$ Stansfeld accordingly moved an address for the production of the papers, on 24 July. 24

Stansfeld's motion specified those papers which were "not too voluminous for production", and he had discussed with the Foreign Office the problems presented by the relatively intractable material. Neither the Foreign Office nor the Local Government Board was prepared to commission a digest, and Staveley suggested (20 July) that the papers might be sent for redaction to a medical expert commissioned by Stansfeld, "always subject of course to subsequent judgment in the department". He proposed that all the papers be sent to Stansfeld's nominee, and subsequently made available to the House, in manuscript, so that members could judge for themselves the selection made for publication. Bourke rather reluctantly agreed to this procedure, and Derby as Foreign Secretary also consented, with the proviso that the result be scrutinized to ensure that it favoured neither side of the controversy. Bourke therefore accepted Stansfeld's suggestion, emphasizing that the Foreign Office would not be able to arrange the necessary scrutiny, and on 9 August 1877 the papers were

${ }^{20}$ Smith, op. cit., note 2 above, pp. 127-134. For rival memorials addressed to the prime minister, see H.C., 1871, 56, no. 184.

${ }^{21}$ The commission described its own origins: H.C., 1871, 19, paras 16-17. Its report, though temporising and ineffectual, was markedly hostile to the abolitionists.

21 Johnstone was the leader of the repealers in the Commons until the more effective Stansfeld superseded him: Hammond and Hammond, op. cit., note 2 above, p. 190.

20 FO 83/521,13, 14, and 18 June 1877; FO 83/522, 12, 13, 17, and 18 July 1877; FO 83/557, Staveley's minute of 16 June 1877 filed at 2 May 1878.

« FO 83/522, 24 July 1877. 


\section{A Foreign Office survey of venereal disease and prostitution control, 1869-70}

sent to Stansfeld's nominee. ${ }^{25}$ This was John Birkbeck Nevins, of Liverpool. Stansfeld's choice was understandable, but injudicious; Nevins was an experienced provincial consultant of wide medical and literary interests, but he was also a zealous campaigner against the acts, subsequently giving evidence to a select committee in his capacity as president of one of the abolitionist associations, ${ }^{26}$ and his allocation to this particular task meant that the Foreign Office would always have a residual ground for objecting to the publication of any analysis he might produce. ${ }^{27}$

After some prompting, ${ }^{28}$ Nevins produced his report, which he delivered to Staveley at the Foreign Office on 12 February $1878 .{ }^{29}$ Presumably in consequence of the conversation then, Nevins put in writing to Tenterden, Bourke's immediate colleague, the nature of his additions to the material he had been given, and Staveley proposed that Stansfeld should decide whether or not these materials, extraneous to the original brief, should be allowed to remain. Tenterden concurred, and the report was forwarded to the Local Government Board; the covering letter stated that Stansfeld had accepted the additions, and that the Board should now inspect the report for publication. The reply was not encouraging. The Board, according to one of its assistant secretaries, was suspicious of Nevins' known bias and would therefore insist on detailed scrutiny of his analysis, but could not possibly stretch its own resources to provide a suitable person. Since the Foreign Office felt similarly unable to review the work, Staveley suggested that the Treasury might subvent a referee nominated by the Board, but the idea was not accepted. Six months later Staveley noted that the whole business had petered out. Correspondence with Stansfeld had been inconclusive, and a proposal (2 October) that the Commons address might be "discharged on the proper formalities being gone through", failed to elicit any reply. Nevins had by this time alienated the Foreign Office by publishing, or attempting to publish, some of the material in his abolitionist tracts; the consequent reprimand had the desired effect, since Nevins' subsequent evidence before the select committee, while including comparative evidence from various countries, was apparently based only on private investigations, without use of the Foreign Office papers. Staveley's note, indeed, was the last official word on the survey; ${ }^{30}$ the select committee decided, to Stansfeld's evident disgust, to exclude foreign evidence from its consideration. ${ }^{31}$

Nevins' analysis of the returns justified in many respects the official fears that his work would favour his own cause. ${ }^{32}$ Its presentation shows signs of haste; the returns from The Netherlands, where controls were claimed to be effective, were ignored, ostensibly because of the language difficulty; and the balance of the work is impaired by the incorporation of material extraneous to the survey as such. Nevins told Tenterden that he had supplemented the papers by reference to army and navy reports, a

${ }^{25}$ FO 83/522, 20, 27, and 28 July, and 4, 6, 9, and 10 August 1877.

${ }^{26}$ H.C. 1880, 8, no. 114, Qs 3, 19. See also Hammond and Hammond, op. cit., note 2 above, pp. $191-192$.

${ }^{27}$ See the obituary in The Times, 12 June 1903, p. 10e.

28 FO 83/522, 20 December 1877; FO 83/591, 20 December 1877; FO 83/556, 20 January 1878.

29 FO 83/556, 31 January, 5 and 7 February 1878.

${ }^{20}$ FO 83/556, 15 and 25 February, 7, 28, and 30 March 1878; FO 83/556, 2 October 1878; H.C. 1880,8 , no. 114, Qs. 80-84.

"1 Hammond and Hammond, op. cit., note 2 above, p. 225; H.C., 1882, 9, pp. iii, xli, 1x.

${ }^{32}$ The analysis is now FO 83/575. 


\section{J. B. Post}

return by F. W. Lowndes, a secretary of the association for the extension of the acts, and material from the War Office, Home Office, and Admiralty;33 he did not mention other sources, such as Parent-Duchatelet, ${ }^{34}$ nor did he mention a gratuitous chapter, a description of which occupies half the general introduction, on the recent moral resolutions passed by various British and international organizations dedicated to the repeal of state control of prostitution. The tone of Nevins' own contributions is imparted to the analysis as a whole; his précis of the Hamburg report, for example, is much more moralistic than the original, and he gave a disproportionate amount of space to the often vague returns from Switzerland, where there were virtually no controls. The result may not be overtly fraudulent in any particular, but the general impression given is unwarrantably far from the diverse but often confident and optimistic comments of those administering systems of close control.

Thus the labour devoted to the Foreign Office circular and its returns, and the interest expressed in them, had no direct outcome. ${ }^{35}$ After 1869 the rapid decline of support for extension of the acts, and Simon's discouraging attitude, curbed the original governmental enthusiasm. Later, when British repealers were participating in international agitation, it seemed that the returns might be resurrected, but Stansfeld's ill-judged choice of Nevins, and the uninterested co-operation of justifiably cautious civil servants, ensured that the movement for repeal proceeded to its success in the 1880 s without the aid of these rich and varied materials.

\section{SUMMARY}

In 1869, in response to agitation for reform of the Contagious Diseases Acts, the Privy Council commissioned from the Foreign Office a comparative survey of foreign controls and legislation concerning venereal disease. Although the materials collected were never put to official use, their content and their history are of interest for the study of venereal disease and for the study of government attitudes towards it.

\footnotetext{
33 FO 83/556, 15 February 1878.

34 A.-J.-B. Parent-Duchatelet, De la prostitution dans la ville de Paris . .., 3rd ed., Paris, 1857.

${ }^{25}$ See also India Office Records, L/MIL/7/13809-13923.
} 